\title{
MONOPSONISTIC BEHAVIOR IN CHILEAN MANUFACTURING
}

\author{
COMPORTAMIENTO MONOPSONICO EN LA \\ MANUFACTURA CHILENA
}

\section{DAVID MACKINSON*}

ILADES-Universidad Alberto Hurtado

\section{LUCAS NAVARRO**}

ILADES-Universidad Alberto Hurtado

\begin{abstract}
This paper uses a firm-specific method for measuring monopsonistic behavior developed by Brummund (2012) using data for Chilean manufacturing plants for the period 2001-2006. We find that there is significant heterogeneity in labor market power across plants and that nearly a quarter of the plants have a significant level of labor market power. It is also shown that individual plant characteristics explain more of the variation in monopsonistic behavior than do the characteristics of the accompanying labor market. These results are relevant for labor market policy since and suggest that a binding minimum wage could have ambiguous effects on welfare.
\end{abstract}

Keywords: Monopsony, labor markets, Chile.

JEL Classification: J42, O12, L12.

* Erasmo Escala 1835, Santiago de Chile, Chile. Phone: +56 2 2889 7356. E-mail: dmackin2@gmail.com

** Erasmo Escala 1835, Santiago de Chile, Chile. Phone: +562 2889 7356. E-mail: lunavarr@ uahurtado.cl 


\section{Resumen}

Este trabajo utiliza una metodología firma-específica desarrollada por Brummund (2012) para medir poder monopsónico en el mercado de trabajo usando datos de plantas manufactureras chilenas para el período 2001-2006. Los resultados muestran una alta heterogeneidad en poder de mercado laboral entre las plantas y que cerca de un $25 \%$ de las plantas tienen un nivel alto de poder monopsónico. Se encuentra también que las características individuales de las plantas tienen un mayor poder explicativo del comportamiento monopsónico de las plantas que las características agregadas del mercado laboral en el que se desempeñan. La implicancia de política de estos resultados es que un salario mínimo restrictivo podría tener efectos ambiguos sobre el bienestar.

Palabras clave: Monopsonio, mercado de trabajo, Chile.

Clasificación JEL: J42, O12, L12.

\section{INTRODUCTION}

If firms have monopsonistic power in the labor market they would set wages such that workers would be paid below their marginal contribution to output in real terms. Following Pigou (1924), the standard empirical measure of monopsony in the labor market is the difference between a worker's marginal revenue product MRPL and the wage $W$, relative to the wage. Pigou's measure of labor market power is then defined as $E=\frac{M R P L-W}{W}$. The inverse of this measure is the elasticity of the labor supply curve facing the firm. Evidence of monopsonistic behavior generally means that fewer workers are employed and at lower wages than would be if firms were operating in a more competitive labor market. In this context, a minimum wage policy could have a positive effect on both employment and wages. In modern labor market theories, the existence of search frictions leads to firms' monopsonistic power in wage setting even in otherwise competitive labor markets. The fact that looking for a job is costly in terms of time and effort implies that workers would find it worth to accept wages below their marginal product instead of continuing searching for better job offers.

This paper follows closely a method developed by Brummund (2012) to quantitatively estimate the level of labor market power among Chilean manufacturing firms and its determinants, i.e., whether firms' labor market power is more attributable to traits specific to the firm or rather to traits specific to the labor market in which they participate. The paper uses plant level data from the National Survey of Manufacturing (Encuesta Nacional Industrial Anual, ENIA) for the period 2001-2006. 
Brummund (2012) develops a method for measuring market power that yields firm-year specific measurements. By using a panel of manufacturing establishments in Indonesia, he calculates the marginal revenue product of firms directly by evaluating the derivative of the firm's production function at their observed level of inputs. $\mathrm{He}$ then compares the marginal revenue product of labor to the wage each firm pays its workers in order to construct Pigou's measure of monopsonistic behavior. The paper finds that over half of the manufacturing establishments in Indonesia have a significant amount of market power. The median level of the measure $E$ of monopsonistic behavior found is 1.67. Additionally, it is found that individual firm characteristics explain more of the variation in monopsonistic behavior than do the characteristics of the labor market in which the firm participates. This direct approach for measuring monopsony has been used before however. Boal and Ransom (1997) spell out much of the theory behind the direct measurement of wage and marginal revenue product in their work although they make the observation that this technique does not identify the sources of monopsonistic power. Scully (1974) is arguably the first work to conduct empirical research in testing for monopsony. This work estimated the marginal revenue product of individual professional baseball players and directly comparing that to their wages. Until 1976, the "reserve clause" in player contracts bound each player to a single team. As a result of this collusion, teams did not compete for players. In the study, Scully separates the players by position (pitchers and catchers) and skill level (mediocre, average, and stars) and finds that players were paid less than half of the value of their contribution to output.

This paper follows Brummund (2012) in obtaining plant specific measures of labor market power by year from Cobb-Douglas production function estimates. After estimating this plant-year "mark-down" on wages, we provide evidence that this is indeed consistent with the traditional definition of monopsony - that firms in highly concentrated labor markets have more market power than firms in less concentrated markets. Additionally, we test whether firms with a higher share of blue-collar workers have higher levels of market power. We find that nearly a quarter of the firms in the Chilean manufacturing sector present a significant amount of labor market power. Regarding blue-collar workers, the average level of labor market power (the $E$ measure) is 1.60 , which translates to a labor supply elasticity to the firm of 0.62 , for white-collar workers the estimates of labor market power are even greater. The estimated median levels of labor market power for both types of labor are 0.21 and 0.59 . These values are quite low compared with what Brummund (2012) found for Indonesia. Finally, we use the distribution of labor market power across firms to show that individual firm characteristics are more important in explaining a firm's market power than is the labor market the firm participates in.

The paper highlights the complexities in setting an appropriate minimum wage policy. If firms behave monopsonistically, they will hire fewer workers at lower wages, both outcomes negatively impacting the welfare of workers. In this context, a minimum wage could increase efficiency by both raising workers wages and increasing the number of people employed. However, if firms in the same labor market have 
different levels of market power and if that behavior is more a product of firm-specific characteristics, then a market wide minimum wage policy will have mixed results, changing the overall cost-benefit analysis.

This paper is structured as follows. The next section reviews the empirical methods and Section 3 describes the data set. Section 4 presents the results, and Section 5 concludes.

\section{METHODOLOGY}

\subsection{Measure of labor market power}

Evidence of monopsonistic behavior is one example of imperfect competition. The concept of a non-competitive labor market was brought into focus by Joan Robinson (1933) who is credited with the notion that firms may have some market power over their workers. According to classical economic theory, a firm should pay workers their marginal revenue product. This paper takes a direct approach at testing for monopsony by measuring the marginal revenue product of labor for manufacturing establishments and comparing it with the wages of each firm. The difference between these two values is the surplus generated by the labor employed at that firm.

A profit maximizing monopsonist will set wages where: $R^{\prime}(L)=W(L)+W^{\prime}(L) L$ in which $R^{\prime}(L)=M R P L$ (marginal revenue product of labor) and $W(L)+W^{\prime}(L) L=M C L$ (marginal cost of labor). In the competitive framework, firms hire up to the point where $R^{\prime}(L)=W$. The difference between this condition and the classic competitive treatment is that the wage is a function of labor, and not constant. Pigou's measure of monopsonistic behavior is thus given by:

$$
E=\frac{R^{\prime}(L)-W(L)}{W(L)}
$$

The inverse of this measure is the elasticity of the labor supply curve facing the firm,

$$
E=\epsilon^{-1}=\frac{W^{\prime}(L) L}{W(L)}
$$

If firms behave monopsonistically $W^{\prime}(L) L>0$ and Pigou's measure is thus strictly positive. If firms behave competitively, $E=0$ and the labor supply elasticity facing the firm would be infinity.

Since we have information on the real wages, the key step in generating this measure of market power $E$ is to develop a credible estimate for the marginal revenue product of labor (MRPL). Brummund (2012) estimates a firm's production function and then evaluates the derivative of the production function at each firms' current levels of revenue and employment to get a firm-year specific measure of $M R P L$. In this 
paper we estimate Cobb-Douglas production functions by groups of manufacturing industries following the Levinsohn and Petrin (2003) technique to control for the correlation between unobservable productivity shocks and input levels. The production function estimates considered as inputs blue and white collar labor, intermediate inputs, electricity consumption and capital.

We then proceed to estimate the production function separately per two-digit industry code. The reasoning behind having more than one parameter is to weaken the assumption that all firms in the estimation sample share the same technology. Thus, this two-digit classification was done by using the ISIC (International Standard Industry Classification) codes for economic activity. The industries under consideration include 9 subcategories (codes $31-39$ ) within manufacturing. With these industry specific estimates for the parameters of the production function, we can obtain estimates of firm-year specific measures for the marginal revenue product of each firm for both blue and white collar labor. In the Cobb-Douglas case this is done by multiplying the estimated coefficient for each industry per type of labor (blue and white-collar) by the average worker productivity by firm-year.

$$
M R P L_{B}=\frac{\partial Y}{\partial L_{B}}=\frac{\hat{\beta}_{L_{B}} Y}{L_{B}} \text { and } \quad M R P L_{W}=\frac{\partial Y}{\partial L_{W}}=\frac{\hat{\beta}_{L_{W}} Y}{L_{W}}
$$

Pigou's measure of firm-year market power $E$ can then be calculated for blue and white-collar workers by subtracting the total wages from the marginal revenue product of labor and then dividing by the total wages.

\subsection{Measure of labor market power and monopsony}

Following Brummund's lead, we will perform a few tests to see if the distribution of values of $E$ is consistent with a view of monopsony. At the firm level, we first test whether firms with higher shares of employment in the local labor market have higher levels of market power. A higher share of total employment for an individual firm should be positively correlated with market power. Each firm's employment share is the ratio of their employment to the total level of employment in their labor market (at the regional level). In this first test we regress the firm market share variable on our dependent variable, Pigou's $E$. The basic idea in running these regressions is to see which (if any) of the variables correlate with this evidence for monopsonistic behavior. We then run a second regression, again using the firm market share alongside several other variables. This includes a measure of annual unemployment for each of Chile's thirteen regions, a measure which controls for new firms post 2001, a measure for firms that have any percentage of foreign ownership, and a measure of product market concentration based on the Herfindahl-Hirschman Index. This second test gives us a better idea of the quality of our firm market share results.

At the market level we then test whether firms in highly concentrated labor markets (where workers have few employment options) have more market power than firms in less concentrated markets (where there are various alternative employers 
available). The number of alternative options (for work) is formalized in measures of concentration of the labor market. A necessary condition for monopsony is that measures of labor market concentration are positively correlated with the estimated firm-level market power $E$. For this third test (and following Brummund's lead), the measure of high and low labor market concentration used in the regressions is the share of employment of blue workers for the eight largest firms in that region that year. In a final test, we regress the estimated measure of $E$ on the aforementioned measure of labor market concentration and controls for regional unemployment, new firms, foreign ownership, and product market concentration.

\subsection{Aggregate and firm-specific variation in labor market power}

In this section of the analysis, we investigate whether the market power found is more attributable to either specific firm characteristics or the labor market in which the firm participates. Results suggesting evidence of the first would confirm traditional theories of monopsony, that the labor market influences the market power of the firms in the market. Results suggesting evidence of the second would support the new theories of monopsony, that firms within the same labor market can have different levels of market power.

Thus, by using the measures of market power for each firm-year observation, Brummund (2012) is able to separate the within-labor market variation from the between labor market variation in market power. This is done by obtaining partial correlation coefficients for different sets of independent variables. The partial correlation coefficient for an independent variable, $X$, captures how much of the overall variation in the dependent variable can be explained by $X$. To calculate the partial correlation coefficient for a variable or set of variables, $X$, we first find the $R^{2}$ from the model with all of the controls and the $R_{X}^{2}$ from the model with variable $X$ excluded. Then the partial correlation coefficient is formulated as:

$$
\rho_{X}=\left(R^{2}-R_{X}^{2}\right) /\left(1-R_{X}^{2}\right)
$$

If the partial correlation coefficient for the labor market controls is larger than the value for that of the firm controls, than the labor market determines more of the variation in market power than do the individual firm characteristics (or vice versa).

To control for labor market variation, Brummund (2012) uses a measure of high and low labor market concentrations (which are calculated by the share of employment of blue-collar workers for the eight largest firms in each region by year), as well as the annual regional unemployment rate. The concentration ratio varies over time and would capture the traditional view of how labor markets influence market power. As local unemployment increases, firms in that labor market should be able to pay lower wages as there are more workers available for any given job. We will also include labor market fixed effects to control for unobserved differences in the labor markets constant over time. 
To control for firm-level characteristics that may impact market power, we include controls for new firms, foreign ownership, output growth, firm size, and product market concentration (based on the HHI index). Firm age could lead to more market power as workers prefer to work for more stable employers. It is also possible that Chilean workers might prefer to work for younger, more dynamic firms in which there is more room for upward mobility. Thus, the sign on firm age could go either way. The correlation of foreign ownership and labor market power could also go either way. Foreign owned firms might be expected to have less labor market power as they are unfamiliar with the local customs and practices, but that would just increase their recruiting costs, and not influence their market power. On the other hand, if workers prefer to work for foreign firms, then these firms would have increased market power. This might be due to foreign firms having greater stability, increased domestic and international recognition, as well as possibly better working conditions. Firm size may also affect product market power, and we use a measure of capital to proxy for firm size. Furthermore, firms with product market power may have a more secure future which is more attractive to potential workers. In this specification, firm level fixed effects control for any time-invariant firm characteristics that influence market power. These could be working conditions that differ across firms, but are not captured in the total labor costs used to construct the $E$ measure of market power.

Summarizing, we will regress the individual firm-year measurements of market power on various firm and market characteristics to see which factors influence market power more. Using the log of Pigou's measure of market power, $e_{i j t}=\ln \left(E_{i j t}\right)$, for firm $i$ in region $j$ at year $t$, as the dependent variable, we will estimate the following specification,

$$
e_{i j t}=\alpha_{0}+X_{i t} \alpha_{1}+Y_{j t} \alpha_{2}+\gamma_{j}+v_{i}+\epsilon_{i j t}
$$

$X_{i t}$ is a set of time-varying firm characteristics (foreign owned, firm age, output growth, and firm size), while $Y_{j t}$ is a set of time-varying labor market characteristics (local unemployment and labor market concentration). $\gamma_{j}$ is a set of labor market fixed effects while $v_{i}$ is a set of firm-fixed effects. The model also includes industry and year dummies (to control for any factors that are constant across all firms in the same year or industry) as well as the number of production employees in each firm (all the models are weighted by the number of production employees in each firm).

\section{DATA}

The data used in this analysis comes from the Economic Commission for Latin America and the Caribbean (CEPAL), as well as the Chilean National Statistical Institute (INE) whom provided the unemployment statistics. It is a census of all the manufacturing establishments in Chile. Firms are required to fill out the survey each year, and the dataset covers the years 2001-2006. This is the most complete dataset 
available of ENIA at the time of writing this paper that has detailed information on different types of labor at the plant level. Each observation is a firm-year. The dataset includes 30,826 observations for 7,711 firms over 98 different industries at the three-digit ISIC levels. The data covers firms that have at least one and at most 5,020 employees.

Table 1 presents a detailed breakdown of employment and wages by position. The idea to label the workers as strictly blue or white-collar came as a result of the wage analysis by position. Based on the titles and wages of each position, owners, directors and specialized workers were considered white-collar workers and workers in the remaining categories were labeled blue-collar. As noted in Table 1, blue-collar workers make on average \$3,628 USD/year which is about $\$ 167,193$ pesos/month. White-collar works make over double that - approximately $\$ 7,709$ USD/year which is about $\$ 355,244$ pesos/month. Wages and all monetary values are all expressed at prices of 2003. Blue-collar workers represent $77 \%$ of total employment in the pooled sample.

\section{TABLE 1}

SUMMARY OF BLUE AND WHITE SALARIES IN THE CHILEAN MANUFACTURING SECTOR

\begin{tabular}{|lrrrrr|}
\hline Position & $\begin{array}{c}\text { Average } \\
\text { year } \\
\text { wage } \\
\text { (USD) }\end{array}$ & $\begin{array}{c}\text { Median } \\
\text { yearly } \\
\text { wage } \\
\text { (USD) }\end{array}$ & $\begin{array}{c}\text { Average } \\
\text { monthly } \\
\text { wage } \\
\text { (CLP) }\end{array}$ & $\begin{array}{c}\text { Median } \\
\text { monthly } \\
\text { wage } \\
\text { (CLP) }\end{array}$ & $\begin{array}{r}\text { Estimated } \\
\text { number } \\
\text { employed } \\
\text { annually }\end{array}$ \\
\hline Owners & 11,869 & 9,298 & 546,944 & 428,483 & 4,722 \\
Directors & 20,639 & 14,479 & 951,121 & 667,237 & 9,013 \\
Specialized & 45,196 & 9,150 & $2,082,763$ & 421,670 & 73,837 \\
Admin. & 4,920 & 3,964 & 226,710 & 182,659 & 33,610 \\
Commission & 6,720 & 4,095 & 309,679 & 188,711 & 20,606 \\
Unskilled Direct & 3,204 & 2,709 & 147,660 & 124,848 & 167,181 \\
Personal Services & 3,451 & 2,703 & 159,012 & 124,563 & 7,029 \\
Specialized Subcontracted & 5,495 & 3,621 & 253,226 & 166,889 & 8,389 \\
Admin. Subcontracted & 4,474 & 3,100 & 206,162 & 142,858 & 2,694 \\
Commission Subcontracted & 5,964 & 3,791 & 274,836 & 174,717 & 3,046 \\
Unskilled Direct Subcontracted & 2,959 & 2,272 & 136,340 & 104,723 & 16,582 \\
Auxiliary Subcontracted & 3,438 & 2,534 & 158,444 & 116,769 & 6,900 \\
Personal Services Subcontracted & 3,285 & 2,631 & 151,384 & 121,230 & 5,079 \\
Auxiliary & 4,334 & 3,486 & 199,745 & 160,647 & 29,462 \\
\hline White Collar & 7,709 & 5,192 & 355,244 & 239,249 & 87,572 \\
Blue Collar & 3,628 & 2,909 & 167,193 & 134,057 & 300,578 \\
\hline
\end{tabular}

Notes: Owners, directors and specialized workers are considered white-collar workers. The remaining categories are blue-collar. The salaries are labeled in annual US dollars as well as monthly Chilean pesos in real terms at 2003 prices. 


\section{RESULTS}

\subsection{Measure of labor market power}

Table 2 presents the results of estimating a Cobb-Douglas production function using the Levinsohn and Petrin (2003) method. The estimated parameters of the production function are presented for the nine industries within the manufacturing sector. With the estimated coefficients for blue and white-collar labor there were obtained estimates of the measure of labor market power for both types of labor.

There were performed a few data cleaning procedures that were relevant to the data at hand. In reviewing the values of market power $E$ found, any value of $E>100$ was replaced with a missing value. This concerned a small percentage of observations (66 values of $E$ for blue-collar and 48 white values of $E$ for white-collar) and tend to coincide with an unrealistic employee salary or firm income. Additionally, there is a significant increase in the value of $E$ when the salaries are uncharacteristically low for white-collar employment (below \$ 5,000 USD/year or \$230,416 pesos/ month). Likewise, there is also a jump in the values of $E$ when the salaries for blue-collar employment fall below the minimum wage limits set during the year in question (any salary below approximately $\$ 2,500$ USD/year or $\$ 115,208$ pesos/ month). In order to remedy these invalid values (or possible outliers), any value of $E>50$ alongside any white-collar salary below \$ 5,000 USD/year was replaced with a missing value. The same was done for any value of $E>50$ alongside any blue-collar salary below $\$ 2,500 \mathrm{USD} /$ year.

Table 3 presents the results for Pigou's measure of market power. The top two lines of the table show the results for blue-collar workers and the bottom two for the white-collar workers. Column (2) shows the mean of market power, weighted by the number of employees in each firm. Column (3) shows the median of the distribution, and then columns (4) to (6) display the percentage of observations that lie in three ranges of values of $E$ used by Brummund (2012). Column (4) reports the percentage of firms with measures of Pigou's $E$ below 0.33 , which can be considered firms with little to no market power. A value of 0.33 , for example, indicates that the workers' marginal revenue product of labor is only $33 \%$ above their wage. Ideally, a competitive firm would pay wages equal to the $M R P L$, and thus $E$ would be equal to a value of zero. Column (5) shows the percentage of firms with measures of Pigou's $E$ between 0.33 and 2, which suggests that they have some market power. For example, a value of $E=2$ indicates that an employee's $M R P L$ is three times higher than their wage. The final column (6) shows the percentage of firms with significant market power $(\mathrm{E}>2)$. 


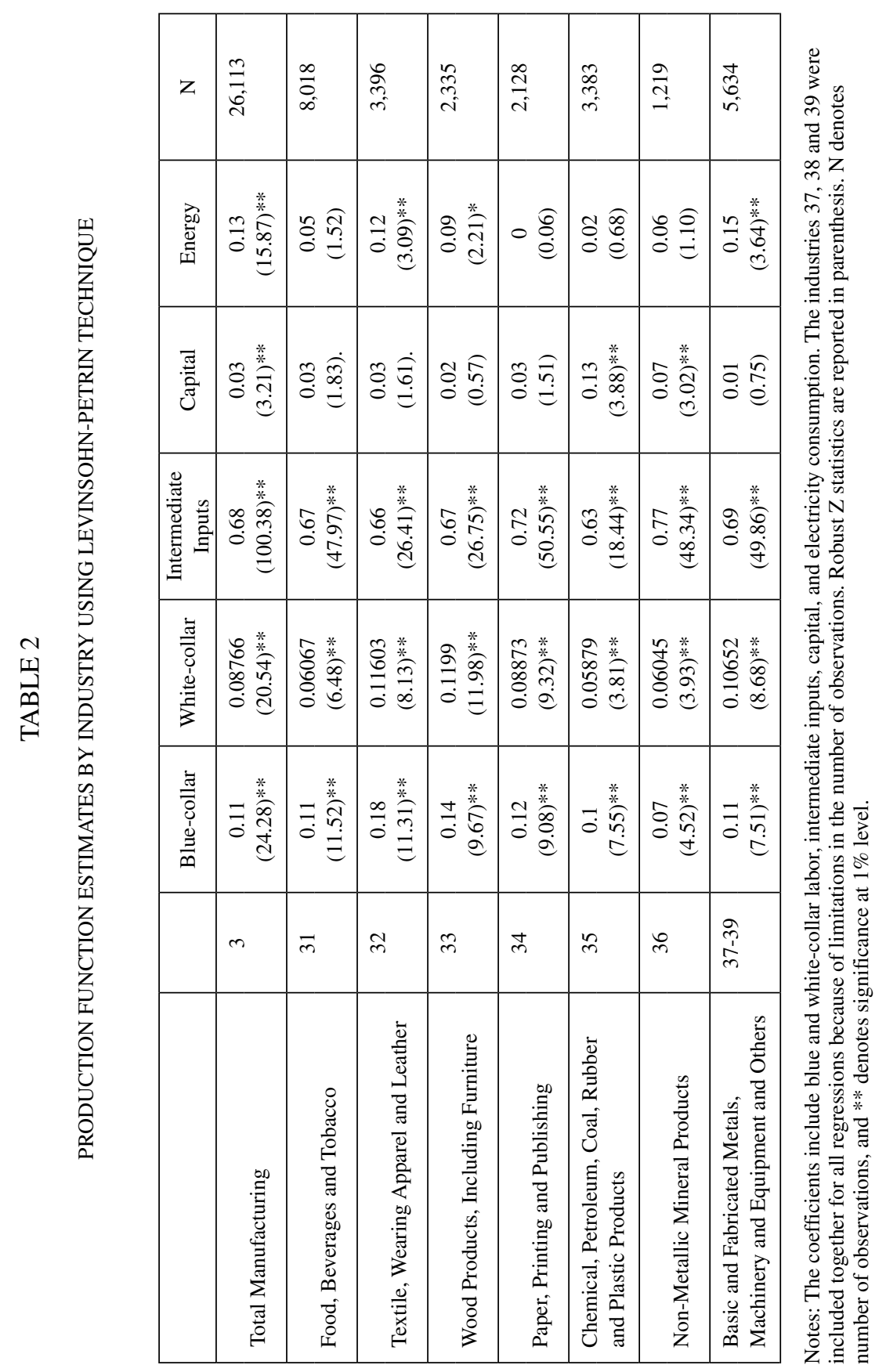


TABLE 3

SUMMARY OF PIGOU'S MEASURE OF MARKET POWER, $\boldsymbol{E}$

\begin{tabular}{|ccccccc|}
\hline & Observations & Mean & Median & \multicolumn{3}{c|}{ Percent of plants with } \\
\cline { 5 - 7 } & $(1)$ & $(2)$ & $(3)$ & $\begin{array}{c}E<0.33 \\
(4)\end{array}$ & $\begin{array}{c}0.33<E<2 \\
(5)\end{array}$ & $\begin{array}{c}E>2 \\
(6)\end{array}$ \\
\hline Blue-Collar & 28,957 & $\begin{array}{c}1.6065 \\
(5.44)\end{array}$ & 0.2125 & 50.88 & 25.58 & 23.54 \\
\hline White-Collar & 26,508 & $\begin{array}{c}2.3569 \\
(5.81)\end{array}$ & 0.5949 & 37.82 & 22.66 & 39.52 \\
\hline
\end{tabular}

Notes: Data covers years 2001-2006. Means are weighted by the number of employees of each type by plant. Standard errors are reported in parenthesis.

As can be seen in Table 3, almost half of the firms have market power, though there is significant variation across firms. The main results are presented in the first row, and show that the median firm for blue-collar labor has a value of Pigou's $E$ equal to 0.2125 which is equivalent to labor supply elasticity to the firm of 4.71 . The median firm for white-collar labor has a value of 0.5949 which is equivalent to labor supply elasticity to the firm of 1.68. The average values of $E$ for white and blue collar labor are $E=2.36$ and $E=1.61$, respectively. Figure 1 displays the kernel density estimate of Pigou's $E$ for blue and white-collar labor. It is possible to see how the density spread of the blue-collar labor is a bit more concentrated at the lower end of range for Pigou's $E$.

The categories regarding blue-collar labor in Table 3 show that $51 \%$ of the firms have little to no market power, whereas $26 \%$ have some market power, and about $24 \%$ have a lot of market power. The categories regarding white-collar labor show that $38 \%$ of the firms have little to no market power, whereas $23 \%$ have some market power, and about $40 \%$ have a lot of market power. These category breakdowns are quite similar to Brummund's results for firms in Indonesia, although the mean and median values of $E$ in this study are lower (Brummund's median and average value of $E$ for production workers were 1.67 and 5.22, respectively).

Also in line with Brummund's results, comparing the top and bottom panels shows that there are more firms with a lot of market power over white-collar workers than firms with market power over blue-collar workers. Brummund (2012) suggests that white-collar workers may be less mobile and not as able to find alternative jobs, while the blue-collar workers are more mobile, more generic. White-collar jobs might require more firm specific human capital, which prevents this type of workers from having a lot of alternative jobs they could switch to. 


\section{FIGURE 1}

KERNEL DENSITY ESTIMATE OF PIGOU'S $E$

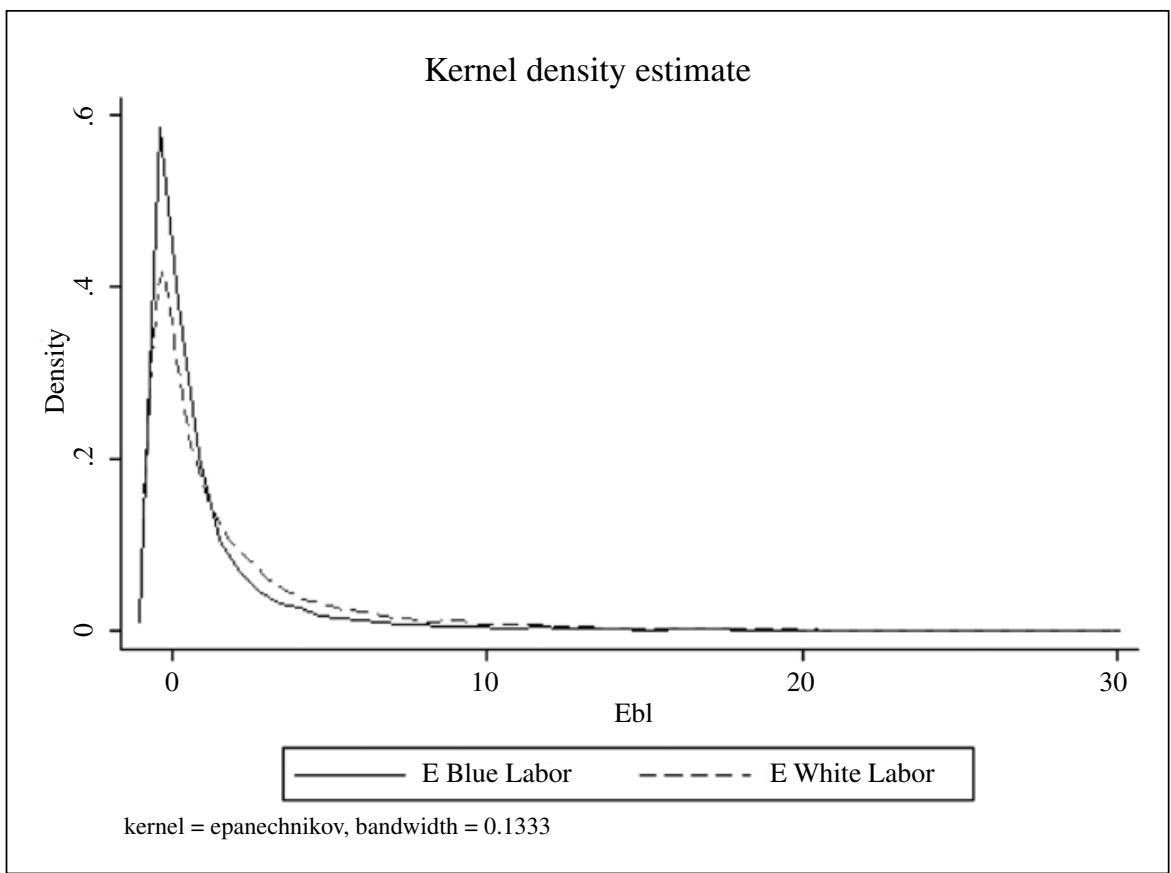

\subsection{Measure of labor market power and monopsony}

Table 4 reports the results of two tests regarding whether the estimated measure of market power is consistent with the traditional understanding of monopsony. We consider for the analysis only the measure of labor market power for blue-collar workers since they account for most of employment among the plants in the sample. The first two columns check if firms that employ a higher share of labor in their local labor market (region) have more market power. The last two columns check whether firms in more concentrated labor markets have more market power. We use the natural log of the measure of market power as the dependent variable, and since some of the firms have values of market power below zero, we add a value of one to each observation prior to taking the natural log. The first column in Table 4 shows the results of a random effects regression using the firm's labor market share as the primary control variable, and also year, industry, and region dummies. The coefficient is positive and significant, as the traditional view of monopsony predicts. Thus, according to these results, the higher the labor market share of the firm (if a firm has a higher share of the total employment within the region), then the higher the measure of Pigou's $E$. 
TABLE 4

CHECKING THE RELATIONSHIP BETWEEN TRADITIONAL MEASURES OF MARKET POWER AND PIGOU'S $E$

\begin{tabular}{|c|c|c|c|c|}
\hline & & endent Var. & (Pigou's $E$ & \\
\hline & (1) & $(2)$ & (3) & (4) \\
\hline Firm Labor Market Share & $\begin{array}{c}0.0426 * * * \\
(0.0079)\end{array}$ & $\begin{array}{c}0.0391 * * * \\
(0.008)\end{array}$ & & \\
\hline Labor Market Concentration - Low & & & $\begin{array}{c}0.0022 \\
(0.0126)\end{array}$ & $\begin{array}{c}0.0042 \\
(0.0133)\end{array}$ \\
\hline Labor Market Concentration - High & & & $\begin{array}{c}-0.0012 \\
(0.0228)\end{array}$ & $\begin{array}{l}-0.0066 \\
(-0.023)\end{array}$ \\
\hline Local Unemployment & & $\begin{array}{c}-0.4843 \\
(.3855)\end{array}$ & & $\begin{array}{l}-0.4517 \\
(0.3921)\end{array}$ \\
\hline New Firms & & $\begin{array}{l}0.0327 * \\
(0.0132)\end{array}$ & & $\begin{array}{l}0.0239 * \\
(0.0131)\end{array}$ \\
\hline Foreign Ownership & & $\begin{array}{c}0.1927 * * * * \\
(0.0301)\end{array}$ & & $\begin{array}{c}0.2124 * * * \\
(0.0298)\end{array}$ \\
\hline Product Market Concentration - Low & & $\begin{array}{l}-0.0226 \\
(0.0133)\end{array}$ & & $\begin{array}{l}-0.0239 \\
(0.0139)\end{array}$ \\
\hline Product Market Concentration - High & & $\begin{array}{l}0.0369^{*} \\
(0.0175)\end{array}$ & & $\begin{array}{l}0.0351^{*} \\
(0.0176)\end{array}$ \\
\hline Constant & $\begin{array}{c}0.5200 * * * \\
(0.0837)\end{array}$ & $\begin{array}{c}0.5138 * * * \\
(0.0979)\end{array}$ & $\begin{array}{c}0.2363 * * \\
(0.0689)\end{array}$ & $\begin{array}{c}0.2569 * * \\
(0.0845)\end{array}$ \\
\hline Overall R - squared & 0.0359 & 0.0445 & 0.0325 & 0.0426 \\
\hline Observations & 28,957 & 28,957 & 28,957 & 28,957 \\
\hline
\end{tabular}

Notes: Data covers years 2001-2006. Standard errors are in parentheses. All models include year, industry, and region dummies, and are weighted by the number of production employees in each firm. Labor market concentration is represented by the share of employment of blue-collar workers for the 8 largest firms in that region that year. High and low is based on the top and bottom quartiles of this variable. Product market concentration is measured by the HHI. High and low product market concentration variables are based on the top and bottom quartiles of the variable.

The second column includes other controls that could influence how much market power a firm has. The coefficient on the firm's market share remains positive and significant. The levels of local unemployment rates appear to have no impact on the measure of market power. In line with Brummund (2012), the coefficient for new-firms is positive and statistical significant, suggesting that new firms hiring new workers have labor market power. Foreign ownership also has a positive and significant impact on labor market power. 
As Brummund (2012) mentions, product market power is not mechanically linked to the measure of labor market power used here. However, workers may prefer to work for monopolistic firms as they may have a more secure future. According to the results of Table 4 this is indeed the case. Only the product market concentration dummy for the high end of the variable is significant (the low end is nearly significant as well), but both have the expected sign (low is negative and high is positive). In greater detail, this means that a large share of non-monopolistic firms (small firms with insignificant shares of market power) within a region would contribute to a smaller measure of Pigou's E. Additionally, the coefficient for product market concentration - high, would seem to say that a large share of monopolistic firms (large firms with significant shares of market power) within a region would contribute to a larger measure of Pigou's $E$. These results are essentially in line with what theory would predict.

The last two columns check whether labor market power is positively correlated with labor market concentration. Following Brummund (2012), we define low and high as the firms in the lowest and highest quartiles of market concentration based on the share of employment of blue workers for the 8 largest firms in that region that year. The firms with medium levels of concentration are the omitted category. The results are inconclusive. Brummund (2012) finds instead a negative and significant coefficient for the lower quartile of labor market concentration. The coefficients for the other variables considered are unchanged with respect to the results of column (2). In summary the results of Table 4 support the claim that the obtained $E$ measure of labor market power is consistent with monopsonistic behavior.

\subsection{Aggregate and firm-specific variation in labor market power}

The next step in the analysis is to investigate the contribution of firm-specific as opposed to aggregate factors to the distribution of $E$. We will take the individual firm-year estimates of market power (Pigou's E) and then regress those on several firm and market characteristics to see which factors influence market power more. The regression will be based only on blue-collar workers. Table 5 presents the results of these GLS models where the controls have been entered systematically to enable the calculation of partial correlation coefficients for each group of controls.

Like Brummund, we consider three regression models in which we use various sets of the fixed effects. All of the models include industry and year dummies (to control for any factors that are constant across all firms in the same year or industry, respectively), whereas the second model includes the labor market fixed effects (region), and the last model adds the firm fixed effects. The even numbered columns list the partial correlation coefficients for each group of controls.

Column (1) includes all of the time varying controls, but it does not include either the market or firm fixed effects. None of the variables regarding labor market variation are significant (this includes the labor market concentrations as well as the annual regional unemployment rate. Several of the firm-level variables however are 
significant. The results suggest that foreign ownership of the firm as well as one year sales growth is both significant and positive. Firm size also affects product market power as the variable for capital (which proxies for firm size) is significant and positive. Finally, both measures of product market concentration are also statistically significant and have the expected signs. The age of the firm is not significantly related to market power according to this regression result.

The overall amount of variation explained by the first regression model in the table, using the overall $R^{2}$, is 0.0939 . Less than $1 \%$ of this variation can be explained by labor market characteristics, whereas approximately $78 \%$ can be explained by firm specific characteristics. The rest of the explained variation is explained by the industry and year fixed effects. Like Brummund's results, these partial correlations show that firm specific characteristics are more important in explaining the overall amount of variation in labor market power than are labor market characteristics, but there is still much of the variation left unexplained.

The second two models introduce labor market fixed effects and then firm fixed effects. According to Brummund, "while these controls can capture unobservable characteristics of the labor market and firm that may influence labor market power; the fixed effects change the interpretation of the results and pose a difficult task for the individual controls to influence the market power of a firm labor market over time". Thus the primary importance in these results is the correlation that can be described by the various sets of controls. However, it is possible to look at the firm specific controls in the second regression model when just the labor market fixed effects are included. These controls attempt to explain the variation within a labor market across firms.

The results in column (3) are similar to those in column (1) except that the product market concentrations are no longer significant. Adding labor market fixed effects to the model actually slightly decreases the overall amount of variation explained (for both labor market and firm fixed effects).

The last model adds plant fixed effects and the results are in column (5). Following Brummund, the foreign ownership and firm age controls are dropped because they do not vary over time in combination with the year effects. The interpretation of the coefficients also changes a bit. They now explain how labor market power changes over time within a firm. With this inclusion of the firm fixed effects, the amount of variation in market power that can be explained has again decreased (it is now approximately $18 \%$ ). This is the opposite of Brummund's results in that he was increasingly able to explain the variation in market power over the course of each of the regression models.

Overall, the results in Table 5 prove that there is more "within labor market variation" in labor market power than there is "between labor market variation". The results are in line with traditional theories of monopsony, that the labor market influences the market power of the firms in the market. The results also are in line with the new theories of monopsony, that there is variation in market power across firms within the same labor market. Thus, we can say that firm characteristics are more important in explaining the overall variation in labor market power. 


\section{TABLE 5}

\section{GLS REGRESSIONS WITH PIGOU'S $\boldsymbol{E}$ FOR BLUE COLLAR WORKERS AS THE DEPENDENT VARIABLE}

\begin{tabular}{|c|c|c|c|c|c|c|}
\hline & \multicolumn{6}{|c|}{ Dependent Var. $=\ln ($ Pigou's E +1$)$} \\
\hline & $\begin{array}{c}\text { Coef. } \\
(1) \\
\end{array}$ & $\begin{array}{c}\text { Partial } \\
\text { Corr. } \\
(2) \\
\end{array}$ & $\begin{array}{l}\text { Coef. } \\
(3) \\
\end{array}$ & $\begin{array}{c}\text { Partial } \\
\text { Corr. } \\
(4) \\
\end{array}$ & $\begin{array}{l}\text { Coef. } \\
(5) \\
\end{array}$ & $\begin{array}{c}\text { Partial } \\
\text { Corr. } \\
(6) \\
\end{array}$ \\
\hline Labor Market Concentration - Low & $\begin{array}{l}0.0168 \\
(0.015)\end{array}$ & \multirow{3}{*}{0.004} & $\begin{array}{l}0.0129 \\
(0.015)\end{array}$ & \multirow{3}{*}{0.000} & $\begin{array}{c}0.0152 \\
(0.0154)\end{array}$ & \multirow{3}{*}{0.000} \\
\hline Labor Market Concentration - High & $\begin{array}{c}0.0179 \\
(0.0193)\end{array}$ & & $\begin{array}{l}-0.0021 \\
(0.0241)\end{array}$ & & $\begin{array}{c}0.0007 \\
(0.0243)\end{array}$ & \\
\hline Low Unemployment & $\begin{array}{c}0.237 \\
(0.3546)\end{array}$ & & $\begin{array}{c}-0.1873 \\
(.4251)\end{array}$ & & $\begin{array}{l}-0.0666 \\
(0.4321)\end{array}$ & \\
\hline Foreign Ownership & $\begin{array}{c}0.1832 \text { *** } \\
(0.033)\end{array}$ & \multirow{5}{*}{0.0732} & $\begin{array}{c}0.1862 * * * \\
(0.0331)\end{array}$ & \multirow{5}{*}{0.0703} & & \multirow{5}{*}{0.1458} \\
\hline Output Growth/100 & $\begin{array}{c}0.3582^{* * * *} \\
(0.0109)\end{array}$ & & $\begin{array}{c}0.3571 * * * \\
(0.0109)\end{array}$ & & $\begin{array}{c}0.3515^{* * * *} \\
(0.0112)\end{array}$ & \\
\hline Product Market Concentration - Low & $\begin{array}{l}-.0297 * \\
(0.0150)\end{array}$ & & $\begin{array}{c}-0.0244 \\
(0.015)\end{array}$ & & $\begin{array}{l}-0.4363 \\
(0.5309)\end{array}$ & \\
\hline Product Market Concentration - High & $\begin{array}{c}0.0443 * * \\
(0.0174) \\
\end{array}$ & & $\begin{array}{l}0.0333 \\
(0.019) \\
\end{array}$ & & $\begin{array}{l}0.0365 \\
(0.021) \\
\end{array}$ & \\
\hline $\ln ($ Capital) & $\begin{array}{c}0.0502^{* * * *} \\
(0.0039)\end{array}$ & & $\begin{array}{c}0.048^{* * * *} \\
(0.0039)\end{array}$ & & $\begin{array}{l}-0.0141 \\
(0.0156)\end{array}$ & \\
\hline Constant & $\begin{array}{c}-0.3065^{* * *} \\
(0.0639)\end{array}$ & & $\begin{array}{c}-0.2372 * * * \\
(0.103)\end{array}$ & & $\begin{array}{c}0.0681 \\
(0.2937)\end{array}$ & \\
\hline Labor Market Fixed Effect & No & & Yes & & Yes & \\
\hline Firm Fixed Effects & No & & No & & Yes & \\
\hline Overall R-squared & 0.0939 & & 0.1005 & & 0.7956 & \\
\hline Observations & 20,488 & & 20,488 & & 20,488 & \\
\hline
\end{tabular}

Notes: The overall R-squared in column (4) is actually the adjusted R-squared.

\subsection{Method and data limitations}

There are a number of limitations on the methodology used to estimate labor market power and in the data that deserve further work. First of all, the production function estimates were obtained using the Levinsohn and Petrin (2003) technique. Even though is useful to control for endogeneity problems, as pointed out by Ackerberg, 


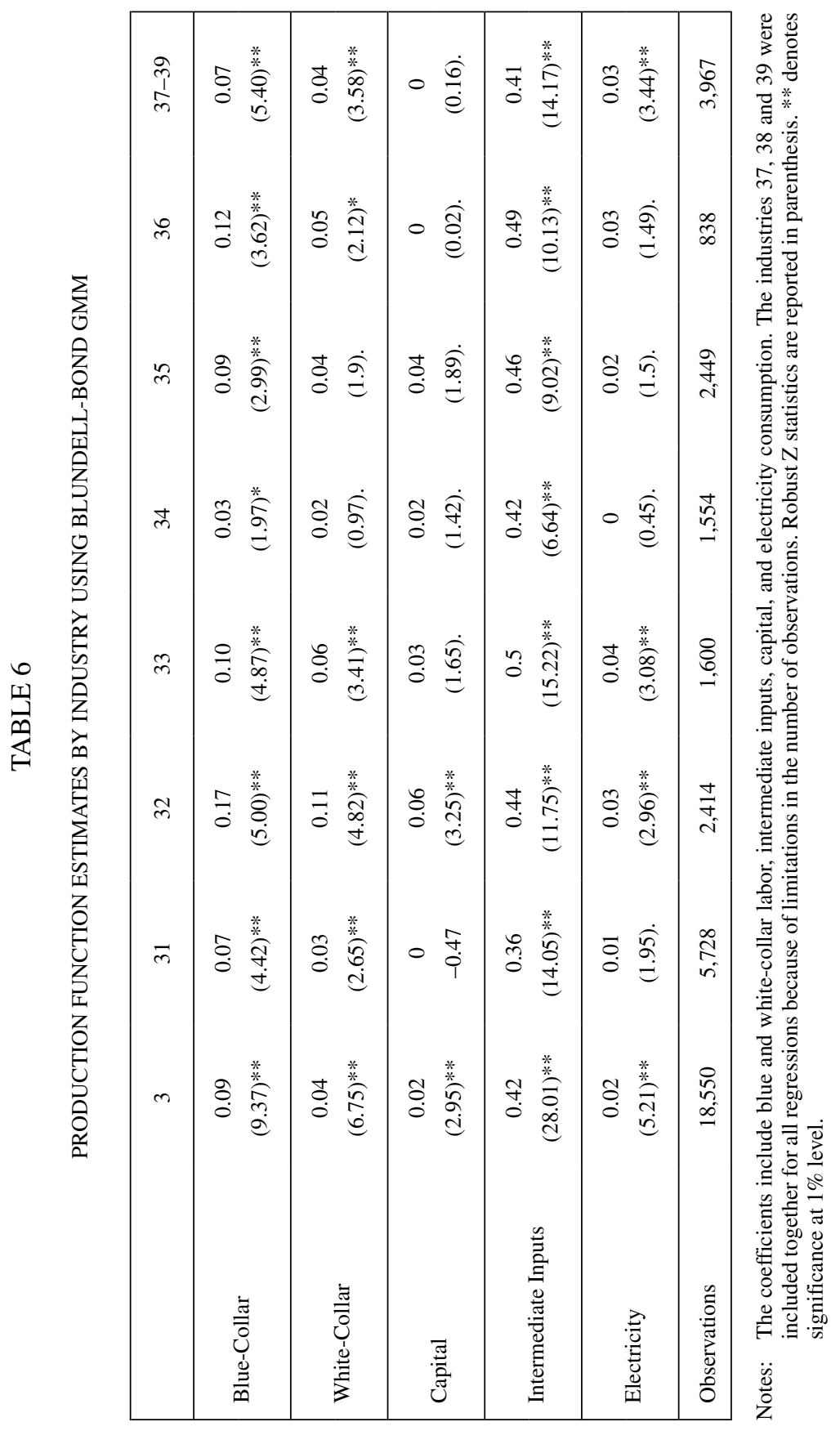


Caves and Frazer (2006) there are multicolinearity issues in the Levinsohn-Petrin identification technique. To avoid these problems, we could have followed the GMM Blundell and Bond (2000) technique like Brummund (2012) even though there are also weak instrument concerns with that method. Table 6 reports the production function estimates using the Blundell-Bond technique. As can be seen in the table, the estimated coefficients for the labor inputs are in all cases not greater than the Levinsohn-Petrin corresponding estimations of Table 2. This would imply higher levels of labor market power than those reported in Table 3, all else equal. One can then interpret our results as conservative in terms of how much labor market power do Chilean manufacturing plants have.

Another aspect in which we can check for the robustness of our results is considering more flexible specifications of the production function apart from the Cobb-Douglas. Finally, our estimates of labor market power rely on average wages for blue and white collar workers but not on individual data, which would give more precision to the analysis.

\section{CONCLUSIONS}

This paper measures monopsonistic behavior in the Chilean manufacturing sector by estimating the marginal revenue product for each firm and comparing that to the wages the firm pays its workers. This was done for both blue and white-collar workers. We find that nearly a quarter of the manufacturing firms present a significant amount of labor market power. It is also shown that individual plant characteristics explain more of the variation in monopsonistic behavior than do the characteristics of the accompanying labor market.

\section{REFERENCES}

ACKERBERG, D.; K. CAVES and G. FRAZER (2006). "Structural Identification of Production Functions", mimeo.

BLUNDELL, R. and S. BOND (2000). "GMM Estimation with persistent panel data: an application to production functions", Econometric Reviews 19 (3), pp. 321-340.

BOAL, W. and M. RANSOMB (1997). "Monopsony in the labor market", Journal of Economic Literature 35 (1).

BRUMMUND, P. (2012). "Variation in Monopsonistic Behavior Across Establishments: Evidence From the Indonesian Labor Market", mimeo Cornell University.

LEVINSOHN, J. and A. PETRIN (2003). "Estimating Production Functions Using Inputs to Control for Unobservables", Review of Economic Studies 70 (2), pp. 317-342.

PIGOU, A. (1924). The economics of welfare. 2nd Edition. London: Macmillan and Co.

ROBINSON, J. (1933). The Economics of Imperfect Competition. Macmillan, London UK.

SCULLY, G. (1974). "Pay and Performance in Major League Baseball", The American Economic Review 64 (6), pp. 915-930. 